\title{
The factors to assess the quality of management of housing and communal services
}

\author{
Elena Agapitova ${ }^{1, *}$, Gennady Chahkiev $^{2}$, and Vera Gerasimova ${ }^{3}$ \\ ${ }^{1}$ Vyatka State University, Moskovskaya str., 36, Kirov, 610000, Russia \\ ${ }^{2}$ Financial University under the government of the Russian Federation, Leningrad pr., 49, Moscow, \\ 125993, Russia, \\ ${ }^{3}$ Moscow State University of Civil Engineering, Yaroslavskoe shosse, 26, Moscow, 129337, Russia
}

\begin{abstract}
The article reveals the author's ideas for improving the quality of management of housing and communal services of a large city. The authors address the issue of expediting the provision of services. The article defined the most important rules and consistency of decisionmaking by managers, providing services to residents of apartment buildings. One of the major challenges is to meet all the needs of residents. The solution to this problem breaks down into two components: the first is the definition itself needs, the second is the determination of ways to meet them. Management involves the implementation of a system of interconnected plans aimed at achieving a common goal. In the market environment of the Russian Federation on management processes overlap with requirements of government regulation, a complex representation which is not available in open sources. A lot of internal regulations contradict each other. Thus, actualizarea scientific problem of allocating the factors of assessing the quality of management of enterprises of housing and communal services that should be considered when developing a unified concept of public administration.
\end{abstract}

\section{Introduction}

Market conditions, the development of the enterprise, its efficiency and competitiveness are directly linked to quality management. The quality of enterprise management is a complex, universal concept. In modern management theory there is no accepted definition. Therefore, it needs further theoretical study.

Category "quality" is traditionally used for products, works, services, because it shows a set of essential properties that characterize the certainty of the subject, in virtue of which he is the data, not different. Quality is the totality of qualities or characteristics of the products or services that give them the ability to meet due or anticipated needs. When it comes to the quality of products (works, services), refers to the complex of consumer properties, each of which is amenable to physical measurement or set by comparison. Therefore, the quality of

\footnotetext{
* Corresponding author: agapitovae@inbox.ru
} 
any object is determined by comparing its properties with the properties characteristic of the sample (standard): the closer these properties to the standard, the higher the quality.

\section{Methods}

The definition of "quality control" in the literature is quite rare. The most complete definition is given in V. Vinokurova: "Quality management is a set of properties inherent in the management and defining its status, the ability to create the appropriate conditions by selecting and integrating a combination of factors internal and external environment to provide the required competitiveness of the enterprise" [1-8].

The author's definition of quality governance is as follows: the set of characteristics of the management providing functioning and development of the site in order to meet the basic needs of the consumer. Distinctive features of this definition are the following:

- management is considered as a system, and its quality is determined by the quality of the elements of the system;

- management is of high quality, if not only provides function, but also the development of the facility;

- management quality is measured by customer satisfaction.

After analyzing research and publications on the topic of improving the quality of governance, we can distinguish three different approaches. Economists who adhere to the first approach, the quality of management is determined on the basis of efficiency indicators for its activities. Authors such as B. E., V. Vinokurov, E. Lubochnia, A. Svirina, N. Nelyubova, V. Kolpakov, etc. are based on the evaluation of indicators of efficiency of activity of the enterprise and on the basis of the results of the assessment determine the problem management subsystem.

So, B. E. writes that "to judge the quality of governance should be only on the basis of the evaluation of the object of control, which, in turn, is determined by the quality of the product (service) activities. Thus there is a chain of causality: quality of management quality of functioning of object of management - the quality of the product generated by the control object" [8]. The author further notes that undoubtedly the quality of products, works and services evidence of good management, but may not be recognized as the only valid.

V. Kolpakov notes that "quality management is the condition and measure; the status of management capacity and the extent of its use, as reflected in the results (including market) of the company and of its components" [6].

$\mathrm{V}$. Vinokurov stressed that from an economic point of view to consider the quality of management outside the system of relations of production, sales and consumption of products impossible. So the quality control is always associated with such basic concepts as market performance and managerial capacity. Proper quality control cannot be achieved without knowledge of the key areas of competence (areas where the company has or may obtain a competitive advantage) and the ability to translate this knowledge into results: sales, profit, and profitability. The author further notes that the office can be seen as a function of numerous and various internal factors: the professionalism of managers, efficiency of communications, the system of managerial decision-making, the equipment with modern technical means [2].

N. Nelyubova in their work [4] as one way of improving the quality of enterprise management describes the balanced scorecard (BSC). Construction and implementation of the balanced scorecard at the enterprise allows to establish the relationship between goals and key performance indicators, and to identify reserves growth targets for the activities of the economic entity. 
Thus, the representatives of the first approach, the quality of management is determined by the performance of the enterprise. According to the classical scheme the effectiveness of the commercial enterprise is the ratio of profits and costs of products or services. The higher the profit per 1 ruble costs, the more efficient the company operates. However, this indicator is not applicable to the organizations of housing and communal services, as the main purpose of management of housing and communal services is the provision of the greatest possible amount of service at the lowest prices and good quality. Therefore, the problem of determining the quality of management of housing and communal services will be the resolution of the contradiction in the understanding of the efficiency between producers and consumers of housing services.

We believe that to the fore in the evaluation of activities of subjects of housing and communal services, should be indicators that characterize the state of the control object (the communal infrastructure and housing) and satisfaction of consumers are indicators of the social performance management (accessibility and comfort of housing, reliability, quality of services, etc.).

The authors of the second approach, the quality of business management is determined by the quality management system elements: goals, objectives, functions, technologies, etc, M. Miller, Z. Vdovenko, O. Krivoruchko elementwise offer to analyze the control system taking into account the linkages between the elements. M. Miller argues that the analysis of management systems should be a complex and purposeful process of studying the status and trends of key elements of management systems, adoption and implementation of managerial decisions within the framework of certain objects in their interaction with the larger and similar systems and managed objects [2,10-13].

The author proposes the methodology of complex analysis of the control system are:

- analysis of organizational and production structures of the object;

- analysis of organizational structures of management in the vertical and horizontal sections;

- analysis of self-supporting status of enterprises and their units;

- analysis support subsystems, including information, personnel, technical provision of a control system.

For example, one of the most important elements of the management system is the goal. The purpose is the main core, which is formed around management activities. About the importance of goals in the life of society is mentioned in many writings of the thinkers of the past. Thus, Aristotle said, "what is good everywhere depends on the condition of two conditions:

- the right to establish the ultimate goal of all kinds of activities;

- finding appropriate means, leading to the ultimate goal."

The importance of targets is that it is based on these are formed of tasks, functions, technologies and management tools.

\section{Results}

The relevance of goal setting lies in the fact that this issue has so far not received adequate justification to management theory and practical experience suggests that errors in choosing goals, negative for society the results over a long period.

Since the objectives of municipal management are reflected in the normative legal acts and Federal target programs, we consider it appropriate to analyze Federal programs and legislative acts in the sphere of housing and communal services (Table 1).

It should be noted the predominance in the policy documents of the General formulation of objectives, without specifying them. For example, the goal "improving the quality of services." This goal does not represent what the service was going on, what the quality 
needs to improve. The documents missing from the hierarchy of objectives, there is repetition purposes without their refinement and development. The shift toward a less specific wording suggests that the goal may not be achieved.

The initial crudity of the wording of the goals the legislator does not provide a clear picture of the functioning of the housing and its end result.

Since the formation of programme objectives at the regional level is dependent on legislation at the Federal level, we will conduct additional analysis of the actions of the authorities housing and communal services at the regional level.

Table 1. Examples of setting targets for housing development on the Federal level.

\begin{tabular}{|c|c|}
\hline The name of programs & Goal \\
\hline $\begin{array}{l}\text { Strategy of development of housing } \\
\text { and communal services in the } \\
\text { Russian Federation until } 2020 \\
\text { [http://www.minstroyrf.ru/docs/396 } \\
\text { 2/]. }\end{array}$ & $\begin{array}{l}\text { 1. Improving the comfort of living conditions; } \\
\text { 2. Improving the quality of housing stock; } \\
\text { 3. Modernization and energy efficiency of housing and } \\
\text { communal services; } \\
\text { 4. Ensuring availability of utility services. }\end{array}$ \\
\hline $\begin{array}{l}\text { The Federal target program } \\
\text { "Dwelling" on } 2002-2010 \text {. } \\
\text { [http://base.garant.ru/2306859/] }\end{array}$ & $\begin{array}{l}\text { 1. Attraction of investments into housing and communal } \\
\text { complex; } \\
\text { 2. Ensure the availability of housing; } \\
\text { 3. Improved stability, reliability and efficiency of } \\
\text { functioning of housing and communal complex; } \\
\text { 4. Improving the quality of housing and communal } \\
\text { services, while reducing inefficient costs (including } \\
\text { through the implementation of energy efficiency } \\
\text { measures); } \\
\text { 5. Improvement of addressed social protection of the } \\
\text { population in terms of payment for housing and } \\
\text { communal services on the basis of the transition to a new } \\
\text { economic model of housing reform; } \\
\text { 6. The Development of market mechanisms of functioning } \\
\text { of housing and communal services. }\end{array}$ \\
\hline $\begin{array}{l}\text { Complex program of modernization } \\
\text { and reforming of housing and } \\
\text { communal services for 2010-2020" } \\
\text { [http://www.consultant.ru/documen } \\
\text { t/cons_doc_LAW_97439/] }\end{array}$ & $\begin{array}{l}\text { 1. Improving the efficiency, sustainability and reliability of } \\
\text { housing and communal life support systems of the } \\
\text { population; } \\
\text { 2. Attraction of investments into housing and communal } \\
\text { complex; } \\
\text { 3. Improving the quality of housing and communal } \\
\text { services, while reducing unsustainable costs. } \\
\text { 4. Targeted social protection of the population at payment } \\
\text { housing-utilities. }\end{array}$ \\
\hline
\end{tabular}

After analyzing the function and purpose for various levels of management utilities, there are certain negative points:

1. at the Federal and regional levels there is a lack of clearly defined goals and objectives;

2. there is a duplication of roles and objectives at different levels;

3. at the Federal and regional levels is observed substitution of terms goals and objectives, there are also significant differences in wording;

4. in fact, each successive level of management only clarifies and implements the functions upstream. 
Goal setting is a difficult and time-consuming process that requires great professionalism and creativity of the performers, due to the objective difficulty of identifying targets. We believe that in formulating objectives, it is necessary to fulfill the following conditions:

1. to Determine and to identify the most important needs, given that the funds available to meet the needs is limited. Therefore, you should make the decision about what needs and in what extent should be met first.

2. to Allocate the available resources to meet needs so that their lack was to the greatest extent overcome.

By definition of a number of authors, the goal can be thought of as options for meeting the primary needs, selected from a set of alternatives, and the result is as a measure to achieve a specific goal.

A third approach to the definition of quality management is determined by the quality of administrative work. Scholars of this approach believe that professional skills, knowledge, abilities and skilled action

Director and specialists ensure efficient operation of the enterprise. So, American economists T. Peters and R. Waterman pointed to the relationship that exists between production processes and those who implement them. They found that effective management can be the style personnel, and the amount of skills, shared values, which was attributed to the "soft" controls. The advantage of the concept is that it changes the traditional views on such issues as structure, management personnel, the separation of powers, attitude to change, work conflicts, and other General organizational problems [6,14-15].

P. Drucker in his work "the Practice of management" showed some practical components affecting the efficiency of administrative work: first, the ability to control your time; second, the concentration of managerial decisions on the end result; third, strong quality of governors; fourthly, managers need to make effective fundamental solutions [5, 14].

Corresponding member of RAS A. G. Porshnev determines the quality of governance through the following characteristics of managerial work:

- creativity as a form of intellectual labor;

- initiative (initiative);

- efficiency;

- innovation;

- responsibility (legal, social, moral), etc. $[8,13]$.

It should be noted that in the housing the quality of administrative work is at a low level, one of the reasons acts the shortage of professional staff. The education system in this direction is destabilized, there is a missing potential associated with training of grass-roots, middle and senior management for the industry.

\section{Discussion}

Quality can be analyzed in different aspects and from different perspectives. Thus, the authors G. Larionov and D. Vinogradov, the category of "quality" to consider perspectives: philosophical, social, legal, economic (Table 2).

The most meaningful is the economic aspect, when quality is considered as an integrated characteristic of the ability of the enterprise to successfully conduct business. 
Table 2. Approaches to the category of "quality".

\begin{tabular}{|l|l|}
\hline \multicolumn{1}{|c|}{ Position } & \multicolumn{1}{c|}{ Contents } \\
\hline Philosophical & $\begin{array}{l}\text { Category "quality" is a substantial certainty of the object in } \\
\text { which it differs from the other. In turn, certainty of object is } \\
\text { based on the individual properties or their combination. The } \\
\text { property is understood as a way of expressing the specific quality } \\
\text { of an object relative to other objects with which it can interact. }\end{array}$ \\
\hline Social & $\begin{array}{l}\text { Category "quality" means the ratio of individual subjects to the } \\
\text { object. The quality can be considered as a category, depending } \\
\text { on the level of culture, religious and demographic characteristics } \\
\text { of individuals and society as a whole. }\end{array}$ \\
\hline Legal & $\begin{array}{l}\text { Category "quality" is defined as a set of object properties meet } \\
\text { the requirements set out in the legal documents }\end{array}$ \\
\hline Economic & $\begin{array}{l}\text { Category "quality" is seen as the result of enterprise activities to } \\
\text { meet the needs }\end{array}$ \\
\hline
\end{tabular}

Consideration of the category "quality" in relation to the management has some difficulties, which are determined by specific features of management:

- mental work consists of administrative, organizational, informational, technical, analytical and constructive activities;

- the subject of labor is information.

- participation in the creation of material goods and services indirectly, through the work of other employees;

- the result of labor - management decision.

Thus, management represents a particular activity, culminating in the creation of such a specific product like control actions and management decisions. The feature of this product is that it runs in the form of decisions, regulations, plans, programmes, regulations etc. by Itself, it does not satisfy the ultimate needs of the people. Only being transferred to the control object, prompting him to action needed for the subject manner, it leads to the creation of the product, the quality of which meets the needs of the people.

\section{Conclusions}

Among the reasons for the shortage of qualified personnel, we can mention: the absence of a system of vocational educational institutions; systematic work with young specialists; the state order for training of personnel; ensure methodological work; professional standards; the mechanism of personification of responsibility; and certification of personnel. In housing lacking professional standards and qualifying characteristics of posts of heads and experts necessary to perform the work. Managers have no special knowledge and skills, often make mistakes in their work, which leads to gross violations of apartment building and negative consequences of the stay owners $[5,10,12]$.

According to research by the Academy of municipal economy and construction, the proportion of workers housing with higher professional education in 2014 amounted to only $7 \%$. The shortage of professionals in this industry is $47 \%$, and $80 \%$ of senior staff in housing even once after the basic education is not a training program $[11,15]$. That is, to improve the management of housing and communal services it is necessary to organize a system of continuous professional education "training - training - training" staff.

Thus, the quality of management there is an objectively existing category, reflecting the real properties of this activity and due to its orientation, methods of implementation, relationship to other activities. Since quality control is a synthetic concept, then the evaluation system should be multi-criteria. Local indicators and criteria give an idea only 
on certain sides of the quality of governance, whereas the most complete opinion on quality can be done only on the basis of a set of features characterizing all control components.

\section{References}

1. F. Kotler, G. Armstrong, D. Saunders, V. Wong, Principles of marketing: Per.with eng. - 2nd Europ.ed. (Publishing house "Williams", St. Petersburg, 2002)

2. M.V. Miller, Analysis and evaluation of the management system of the enterprises (Finance and statistics, Moscow, 1990)

3. B.A. Raizberg, Course control Economics (Peter, SPb, 2003)

4. A. Fayol, G. Emerson, F. Taylor, G. Ford, The Management of science and art (Respublika, Moscow, 1992)

5. N.G. Verstina, T.S. Meshcheryakova, Biosciences Biotechnology Research Asia, 12 2 (2015)

6. A. Mottaeva, MATEC 73, 07020 (2016)

7. A.B. Mottaeva, A. Zheltenkov, I. Stukanova, S. Ryabichenko, S. Zhuk, MATEC 73, 07026 (2016)

8. I. Polyakova, E. Vasilyeva, Procedia Engineering, 165 (2016)

9. L.V. Nikolova, D.G. Rodionov, A.B. Mottaeva, International Journal of Economics and Financial Issues 6(S3), 1-7 (2016)

10. An.B. Mottaeva, As.B. Mottaeva, International Journal of Applied Engineering Research, 10- 23 (2015)

11. An.B. Mottaeva, As.B. Mottaeva, International Journal of Applied Engineering Research, 11- 9 (2016)

12. E. Stein, N. Taskaeva, E. Chibisova, Procedia Engineering, 165 (2016)

13. T. Miroshnikova, N. Taskaeva, MATEC 73, 07006 (2016)

14. A. Pimenova, S. Kuzmina, N. Morozova, A. Mottaeva, MATEC 73, 07018 (2016)

15. A.I. Shlafman Neft', Gaz i biznes 4, 19-22 (2011) 